\title{
Seroprevalence of ovine brucellosis in the microregion of Teresina, Piauí, Brazil
}

\section{Soroprevalência da brucelose ovina na microrregião de Teresina, Piauí}

\author{
Letícia Soares de Araújo Teixeira' (1) (orcid.org/0000-0003-1630-6904) \\ Joilson Ferreira Batista ${ }^{1}$ (1) (orcid.org/0000-0002-2543-6295) \\ Pedro Henrique Fonseca Silva' (1) (orcid.org/0000-0001-8286-2998) \\ Maria Luiza Lima Cordeiro' (10) (orcid.org/0000-0002-6026-8143) \\ Raissa Costa Amorim' (1) (orcid.org/0000-0001-8243-2998) \\ Louis Henrique Miyauchi Silva' (1) (orcid.org/0000-0002-5653-2263) \\ Tuanny Creusa Medeiros Damasceno' (1) (orcid.org/0000-0001-5575-2785) \\ Marlene Sipaúba de Oliveira ' (1) (orcid.org/0000-0002-6675-023X) \\ Francisco Felipe Ferreira Soares ${ }^{1}$ (1) (orcid.org/0000-0003-2370-7650) \\ Clarissa de Castro e Braga' (1) (orcid.org/0000-0002-2658-9111) \\ Janaína de Fátima Saraiva Cardoso² (1) (orcid.org/0000-0002-4484-4403) \\ Ana Lys Bezerra Barradas Mineiro² (1) (orcid.org/0000-0002-3997-1694) \\ Ney Rômulo de Oliveira Paula * (1) (orcid.org/0000-0002-0484-3748)
}

\begin{abstract}
Among the diseases that affect the reproductive system of domestic animals, brucellosis in the sheep species is important because it generates significant economic losses to sheep rearing. Thus, it is a threat to the growth and productivity of sheep herds. In the face of this problem, the objective of the present research was to identify the prevalence of ovine brucellosis in herds in municipalities of the Teresina, Piauí, Brazil microregion by using the agar gel immunodiffusion assay (AGID) and indirect enzyme-linked immunosorbent assay (ELISA) serological tests. Fourteen municipalities were included in the research. Blood samples were collected from 521 pubescent animals by puncturing the jugular vein. After collection, the samples were submitted to the serological techniques, AGID and indirect ELISA, to detect anti B. ovis antibody. Of the 521 samples submitted to the AGIDtest, 23 (4.41\%) were sera reagent and $498(95.58 \%)$ negative. The indirect ELISA tests, $24(4.61 \%)$ suspect samples and 497 (95.39\%) negative samples were obtained, and there were no reagent animals in this test, only suspect. The seroprevalence of ovine brucellosis in the Teresina, Piauí microregion was $4.41 \%$. Thus, it is possible to identify sheep with reagent serology to infection by $B$. ovis, that is present in municipalities in the state of Piauí, Brazil. Furthermore, AGIDwas shown to be more sensitive in detecting animals that had had contact with the etiological agent of the disease.
\end{abstract}

KEYWORDS: AGID; ELISA indirect; small ruminant.
RESUMO: Dentre as enfermidades que acometem o sistema reprodutivo dos animais domésticos, a brucelose na espécie ovina tem se destacado por gerar prejuízos econômicos significativos à ovinocultura. Dessa forma, apresenta-se como uma ameaça ao crescimento e à produtividade dos rebanhos ovinos. Diante de tal problemática, objetivou-se, por meio desta pesquisa, identificar a prevalência de brucelose ovina em rebanhos pertencentes a municípios da microrregiâo de Teresina, Piauí, por meio dos testes sorológicos, imunodifusão em gel de ágar (IDGA) e ensaio imunoenzimático (ELISA) indireto. Quatorze municípios foram incluídos na pesquisa. Para sua execução, colheram-se, por punção venosa da jugular, amostras sanguíneas de 521 animais púberes. Após colheita, as amostras foram submetidas às técnicas sorológicas, IDGA e ELISA indireto, para a detecção de anticorpos anti-B. ovis. Das 521 amostras submetidas ao teste de IDGA, 23 (4,41\%) foram sororreagentes e 498 (95,58\%) negativas. Quanto ao teste ELISA indireto, obtiveram-se 24 (4,61\%) amostras suspeitas e 497 (95,39\%) amostras negativas, não havendo animais reagentes neste teste, apenas suspeitos. A soroprevalência da brucelose ovina na microrregiáo homogênea de Teresina, Piauí, foi de 4,41\%. Assim, foi possível identificar ovinos com sorologia reagente à infecção por B. ovis, presente em municípios do estado do Piauí. Além disso, a IDGA mostrou-se mais sensível em detectar animais que tiveram contato com o agente etiológico da doença.

PALAVRAS-CHAVE: IDGA; ELISA indireto; pequeno ruminante.

'Centro de Ciências Agrárias, Universidade Federal do Piauí - Teresina (PI), Brazil

2Departamento de Clínica e Cirurgia Veterinária, Centro de Ciências Agrárias, Universidade Federal do Piauí - Teresina (PI), Brazil

*Corresponding author: neyromulo@ufpi.edu.br

Received on: 08/02/2019. Accepted on: 07/07/2020 
In Brazil, sheep herds account for 18.43 million animals. The Northeast region is important for the breeding of this species and concentrates about $63 \%$ of the national herd. It is pointed out that the states of Bahia, Pernambuco, Ceará, and Piauí represent a large part of the number of sheep in the Northeast region, presenting $30,21.3,20$, and $10.4 \%$, respectively. The South region ranks lower than the Northeast, with $23.9 \%$ of the sheep herd, followed by the Midwest, Southeast, and North regions with 5.7, 3.6, and 3.7\%, respectively (IBGE, 2016).

The Brazilian Northeast is classified as a privileged region for economic activities involving sheep, mainly due to the adaptability of this species to the edaphoclimatic conditions of the region. Thus, sheep rearing is indicated as one of the most appropriate activities for the Brazilian Northeast (SOUSA, 2016).

Brucella ovis, the etiological agent of ovine brucellosis, is a facultative intracellular non-encapsulated gram-negative bacterium, with wrinkled colonial formation belonging to the genus Brucella spp. (PESSEGUEIRO et al., 2003). This genus presents ten species that have as their preferential hosts: Brucella microti (infects field mice), Brucella inopinata (infects humans), Brucella abortus (infects cattle), Brucella pinnipedialis (infects marine mammals that alternate their habitat between sea and land, for example, walrus and seals), Brucella melitensis (infects goats), Brucella suis (infects reindeer, pigs, hares, and rodents), Brucella ceti (infects cetaceans), Brucella ovis (infects sheep), Brucella neotomae (infects desert rats), and Brucella canis (infects dogs) (SOARES et al., 2015).

Ovine brucellosis is an infectious, contagious pathology that causes several disorders, especially in the reproductive system of males and females. In females, it can trigger placentitis, miscarriages, birth of weak and stillborn lambs, among other changes. In rams, the development of epididymitis and orchitis is characteristic (GREVE et al., 2011; NOZAKI et al., 2011).

Regarding susceptibility, ewes, unlike rams, seem to be resistant to infection by $B$. ovis, since fewer females are observed presenting miscarriage and perinatal death (active infection), even when covered by infected males (GOMES, 2013). Miscarriages, when present, usually occur in the first month of pregnancy (OSBOURN; KENNEDY, 1966; MUHAMMED et al., 1975). According to GOMES (2013), lambs born of infected females that were able to take the pregnancy to term are usually not infected, even when ingesting B. ovis-contaminated milk. This elucidates that the role of females in the active transmission of the infection is less relevant compared to that of the males.

Among the safest and most used serological tests in ovine brucellosis diagnosis, there are the techniques of agar gel immunodiffusion assay (AGID), indirect immunoenzymatic trial and the complement fixation test (NIELSEN et al., 2008). It is pointed out that the Ministry of Agriculture, Livestock and Supply recommends the AGID as the standard screening test for ovine brucellosis diagnosis (BRASIL, 2004).
Due to the economic importance of the sheep species in the animal origin foodstuffs sector in the Northeast region, the objective of the present study was to identify ovine brucellosis in herds in the municipalities of the homogeneous microregion of Teresina, Piauí, by serological tests.

The study was approved by the Committee of Ethics in the Use of Animals (CEUA/UFPI) of the Federal University of Piauí, protocol number 030/14.

The study was carried out in the municipalities of the homogeneous microregion of Teresina, Piauí. Participating farms were selected randomly and denominated primary units. These sheep rearing primary units have an authentic registration in the Piauí Agricultural and Livestock Defense Agency. A statistically pre-established number of sheep was sampled by random lots from the farms included in the study, according to the number of herds in each municipality. Males and females over six months old were selected, since at this age they would already be in puberty. An expected 50\% prevalence of the disease was admitted to obtain the sample size (n). The level of confidence was $95 \%$, with a variation of $5 \%$ (CLEMENTINO et al., 2007).

The region researched includes 14 municipalities, namely: União, Curralinhos, Teresina, Lagoa do Piauí, Altos, Beneditinos, Coivaras, Demerval Lobão, Pau D'Arco do Piauí, Lagoa Alegre, Miguel Leão, Monsenhor Gil, Nazária and José de Freitas. Twenty-eight farms were visited and information was collected by questionnaires answered by the farmers, and blood samples were collected from crossbred sheep. A total of 521 animals were examined, 51 males, and 470 females, and their blood collected. Later, the samples were desorbed and submitted to the AGID and indirect ELISA tests for anti $B$. ovis antibody research. Both tests were carried out in the Animal Reproduction Physiopathology Laboratory at the Federal University of Piauí.

Blood samples were obtained by puncturing the jugular vein. It is emphasized that the puncture was made immediately after cleaning the region with $2 \%$ iodized alcohol, using vacutainer tubes with red lids (without anticoagulant). The tubes were identified with the animal's number, gender, municipality, and farm. In addition, the identification was registered on a spreadsheet according to each municipality and farm visited for better control of the samples. After blood collection, the tubes were kept in a polystyrene box containing recyclable ice for transport. In the laboratory, the tubes were transferred to stands and kept at room temperature for 30 minutes and then centrifuged at 2,500 g for 10 minutes. After obtaining the serum, serological tests were carried out. Samples (serum) not examined on the same day were stored at $-20^{\circ} \mathrm{C}$.

To perform the indirect ELISA, a specific kit was used to detect anti B. ovis antibody (IDEXX laboratories/IDEXX Switzerland AG), which followed the principle of reaction and consisted of placing samples (serum) in the wells of micromanipulation plates pre-impregnated with $B$. ovis antigen 
and as there was specific anti B. ovis antibody in the samples, there was a link from this to the antigen present in the wells, forming an antigen-antibody complex at the bottom of the plate. The non-linked biological material was removed by the washing solution. Next, an anti-IgG marked with peroxidase was added, which was linked to the antibodies of the previously formed antigen-antibody complex. The nonlinked conjugate is removed by washing and a TMB substrate solution was added. Finally, color appeared after incubation (mean optic density at $450 \mathrm{~nm}$ ), which was gradual and corresponded to the quantity of specific antibodies against B. ovis present in the sample. It is pointed out that all steps of the ELISA were carried out following closely the protocol of the supplying laboratory.

The AGID technique was performed using the kit supplied by the Paraná Institute of Technology that consisted of three flasks containing freeze-dried positive control, one flask containing $4 \mathrm{~mL}$ diluent, and a flask containing dry freezedried antigen composed of soluble particles extracted from the bacteria B. ovis itself (sample Reo 198). The test was performed according to the manufacturer's protocol.

The main objective of the test was the radial migration of antibody and antigen through the agar gel that forms the antigen-antibody complex that precipitates in the gel, giving rise to a line of white coloring in the rosette, specifically between the well containing the serum of the tested animal and the well containing diluted antigen.

The agar gel was elaborated from three-step substances, noble agar, a laboratory-prepared buffer (borate buffer), and sodium chloride, at the quantities of $1.0 \mathrm{~g}, 100 \mathrm{~mL}$, and $10 \mathrm{~g}$, respectively. Next, the gel was heated to homogenize the solvent with the added solutes. Immediately afterward, $18 \mathrm{~mL}$ were placed in Petri dishes. After jellification, the gel was cut using a hexagonal perforator (rosette) containing a central orifice and six peripheral orifices. The orifices were then filled with $25 \mathrm{uL}$ of the test serum (even numbers), $25 \mathrm{uL}$ of positive control, and $25 \mathrm{uL}$ antigen (rosette central well). After filling the wells of each rosette, the plates were transferred to a wet chamber and kept at room temperature.

Readings were taken on three consecutive days, that is, at 24, 48, and 72 hours of incubation. For this, an indirect light source was used with a dark background to verify the formation of precipitation lines. When interpreting the results, a white line (gel precipitation line on the gel) was observed between the positive control sera and the antigen. The serum test where the line formed was similar to the line between the wells of the positive control sera and antigen, which were considered reagent. In the non-reagent serum tests, the opposite to the positive sera tests occurred, that is, they did not present the formation of the white line between the sera and the antigen well.

The results obtained were analyzed by the Microsoft Office Excel ${ }^{\circledR} 2010$ program to calculate the ovine brucellosis prevalence in each municipality studied, and to calculate the total prevalence in the Teresina homogeneous microregion, Piauí.

In the present research, 23 (4.41\%) of the 521 blood samples analyzed by the AGID test were reagent (Table 1). All the samples reagent to this test came from females, and

Table 1. Frequency of reagent, non-reagent and suspect sheep in the agar gel immunodiffusion and enzyme-linked immunosorbent assay serological tests by municipality in the microregion of Teresina, Piauí, Brazil.

\begin{tabular}{|c|c|c|c|c|c|}
\hline \multirow{2}{*}{ Municipality } & \multicolumn{2}{|c|}{ AGID } & \multicolumn{3}{|c|}{ ELISA indirect } \\
\hline & Pos (\%) & $\operatorname{Neg}(\%)$ & Pos (\%) & $\operatorname{Neg}(\%)$ & Sus (\%) \\
\hline Lagoa Alegre & $1(4.34)$ & $22(95.66)$ & $0(0.00)$ & 22 (95.65) & $1(4.35)$ \\
\hline Teresina & $0(0.00)$ & $17(100.0)$ & $0(0.00)$ & $16(94.12)$ & $1(5.88)$ \\
\hline Dermeval Lobão & $0(0.00)$ & $20(100.0)$ & $0(0.00)$ & $19(95.00)$ & $1(5.00)$ \\
\hline Lagoa do Piauí & $1(6.66)$ & $14(9.34)$ & $0(0.00)$ & $14(93.33)$ & $1(6.67)$ \\
\hline José de Freitas & $0(0.00)$ & $122(100.0)$ & $0(0.00)$ & $110(90.16)$ & $12(9.84)$ \\
\hline Monsenhor Gil & $1(1.25)$ & $79(98.75)$ & $0(0.00)$ & $80(100.0)$ & $0(0.00)$ \\
\hline União & $1(1.80)$ & $54(98.18)$ & $0(0.00)$ & $54(98.18)$ & $1(1.82)$ \\
\hline Nasária & $0(0.00)$ & $4(100.0)$ & $0(0.00)$ & $4(100.0)$ & $0(0.00)$ \\
\hline Beneditinho & $5(8.92)$ & $51(91.07)$ & $0(0.00)$ & $55(98.21)$ & $1(1.79)$ \\
\hline Miguel Leão & $2(12.5)$ & $14(87.5)$ & $0(0.00)$ & $15(93.75)$ & $1(6.25)$ \\
\hline Curralinhos & $1(5.00)$ & $19(95.00)$ & $0(0.00)$ & $19(95.0)$ & $1(5.00)$ \\
\hline Altos & $4(12.12)$ & $29(87.87)$ & $0(0.00)$ & $32(96.97)$ & $1(3.03)$ \\
\hline Coivaras & $7(17.5)$ & $33(82.5)$ & $0(0.00)$ & $38(95.0)$ & $2(5.00)$ \\
\hline Pau D’Arco & $0(0.00)$ & $20(100.0)$ & $0(0.00)$ & $19(95.0)$ & $1(5.00)$ \\
\hline Total & $23(4.41)$ & $498(95.58)$ & $0(0.00)$ & 497 (95.39) & $24(4.61)$ \\
\hline
\end{tabular}

AGID: agar gel immunodiffusion assay. ELISA indirect: indirect enzyme-linked immunosorbent assay; Pos: positive; Neg: negative; Sus: suspect. 
there was no reagent male. The same samples were assessed by indirect ELISA, but the anti B. ovis antibody was not detected and only 24 (4.61\%) suspect female animals were identified (Table 1). Regarding the municipalities studied, 64.28\% (9/14) presented reagent animals and, of the farms visited, $53.6 \%$ $(15 / 28)$ presented a reagent animal by the indirect AGID test.

The prevalence of the disease, ovine brucellosis, by municipality, was $6.66,4.34,1.81,1.25,8.92,12.5,12.12$, 5 and $17.5 \%$, for the municipalities of Lagoa do Piauí, Lagoa Alegre, União, Monsenhor Gil, Beneditinos, Miguel Leão, Altos, Curralinhos and Coivaras, respectively. The prevalence in the Teresina homogeneous microregion, Piauí, was $4.41 \%$ (Table 1). The results obtained showed that the disease is present in the studied region.

MENDONÇA et al. (2017) used the AGID technique to detect anti B. ovis antibodies and observed $41(4.40 \%)$ animals reactive to the test of a total of 932 sheep. In the present research, a total of 23 sheep with reagent serology for ovine brucellosis was obtained, a lower number than the study MENDONÇA et al. (2017) developed in municipalities in the state of Sergipe, in the Brazilian Northeast. Regarding the municipalities visited in the state of Sergipe, it was reported that $73.68 \%$ (14/19) had seroreagent animals and 25 of the 54 farms presented at least one animal positive for ovine brucellosis. In the present research, of the 40 municipalities visited, nine had reagent animals. These results are similar, as in both studies there was a difference of only five municipalities that did not present reagent animals.

The research was carried out in the mesoregion of Sertão, Paraíba State, Northeast Brazil. Of the 103 farms studied, 21 $(20,39 \%)$ presented at least one reagent animal, and of the 1,134 sheep, only 59 (5.20\%) were seropositive to the AGID test (SANTOS et al., 2013). The same study highlighted the need to diagnose the disease, ovine brucellosis, before acquiring animals for the farm. Furthermore, the cleaning of the installations where the animals are housed cannot be neglected, since without these hygiene practices the acquisition of new animals becomes a serious risk factor for the existing herd (SANTOS et al., 2013). In the present study, these risk factors were also identified, and the sheep sampled were reared with little attention to health management and without control of the health state of new animals introduced into the herd.

It is pointed out that the animals in the farms were reared in the extensive rearing system. According to ADAMS et al. (1993), intensive rearing favors horizontal disease transmission, as there are high stocking rates in feedlots, in addition to the use of collective milk bottles. Probably, due to other equally important factors, the data obtained in the present study were not as high as the results observed in other studies, such as the findings by EISTEN et al. (1999) in Argentina (18\%) and by AZEVEDO et al. (2004) in the state of Rio Grande do Norte (11.3\%).
In the state of São Paulo, RIZZO et al. (2014) studied the occurrence of ovine brucellosis in rams and ewes with a history of reproductive disturbances and observed that the proportion of reagent sheep was $1.7 \%(5 / 294)$, that is, only one male and four females. The authors further reported that of the 28 herds studied, four presented reagent sheep (14.3\%). The microbial culture of samples such as semen and reproductive organs of Texell breed rams was negative. These data were contrary to the complement fixation test, which was reagent. Thus, RIZZO et al. (2014) concluded that there was no relation between reproductive disturbances and positive serology for ovine brucellosis. However, as in the present study, they also observed the existence of foci and risk factors associated to the dissemination of the disease in the herds.

Comparison of the results obtained in the present study with results from other serological research, such as those carried out by NOZAKI et al. (2004), shows that of the 124 samples reagent to AGID without 2/ME, 117 were negative and only seven were suspect in the ELISA. Regarding the 38 samples considered suspicious by the AGID test without 2/ME, 35 were not reagent and only three samples were suspicious according to the ELISA test. Among the non-reagent samples of the AGID without $2 / \mathrm{M}, 820$ were equally non-reagent and 51 were considered suspicious by ELISA. In both the present study and in the study by NOZAKI et al. (2004), there were samples with results considered suspicious by the ELISA test. According to the recommendations of the OIE, the use of the association of the AGID and ELISA techniques is important, since they increase the sensitivity of the test (NOZAKI et al., 2004).

GREVE et al. (2011) submitted 90 samples to the indirect ELISA and obtained 45 reagent samples. It can be inferred that the reagent samples came from animals that presented clinical history of the disease. However, the other samples (45) non-reagent to the indirect ELISA, coincidentally, came from animals without clinical history of the disease. Thus, these results differ from those obtained in the present study, because no animals reagent to the indirect ELISA were shown. In addition to the 90 samples tested, 448 samples were evaluated from animals with clinical history of other diseases and 11 animals reagent to the test were obtained from these samples, but were not reagent to AGID. Different data from those found in the present study, since $23(4.41 \%)$ reactive animals were obtained in the AGID and were non-reagent to ELISA.

Thus, it was concluded that sheep with positive serology for ovine brucellosis were identified. For this reason, the disease is present in municipalities of Piauí and can harm local sheep rearing. Therefore, health measures should be implemented in the region to minimize the losses caused by the disease. 
ACKNOWLEDGMENTS: The authors thank the group of animal health and reproduction, the Animal Reproduction Physiopathology Laboratory, and the Universidade Federal do Piauí.

FUNDING: This work did not receive any specific grant from funding agencies in the public, commercial, or not-for-profit sectors.

CONFLICTS OF INTEREST: The authors certify that they have no commercial or associative interest that represents a conflict of interest in connection with the manuscript.

ETHICAL APPROVAL: This study was approved by Animal Use Ethics Committee of Federal University of Piauí under protocol number 030/14.

AVAILABILITY OF DATA AND MATERIAL: The datasets generated and/or analyzed during the current study are available from the corresponding author on reasonable request.

AUTHORS' CONTRIBUTIONS: Conceptualization: Teixeira, L.S.A.; Batista, J.F.; Silva, P.H.F.; Paula N.R.O.; Mineiro A.L.B.B. Data curation: Teixeira, L.S.A.; Batista, J.F.; Silva, P.H.F.; Oliveira, M.S.; Braga, C.C.; Cardoso, J.F.S.; Cordeiro, M.L.L. Formal analysis: Teixeira, L.S. A.; Damasceno, T.C.M.; Cardoso, J.F.S.; Soares, F.F.F.; Silva, P.H.F.; Batista, J.F.; Mineiro, A.L.B.B.; Paula, N.R.O. Investigation: Teixeira, L.S.A.; Soares, F.F.F.; Batista, J.F.; Cordeiro, M.L.L.; Silva, L.H.M.; Amorim, R.C.; Braga, C.C. Methodology: Teixeira, L.S.A.; Batista, J.F.; Silva, P.H.F.; Paula, N.R.O.; Mineiro, A.L.B.B.; Cardoso, J.F.S.; Soares, F.F.F.; Braga, C.C.; Oliveira, M.S.; Amorim, R.C. Project administration: Teixeira, L.S.A.; Paula, N.R.O.; Mineiro, A.L.B.B.; Cardoso, J.F.S. Resources: Teixeira, L.S.A.; Batista, J.F.; Silva, P.H.F.; Paula, N.R.O.; Mineiro, A.L.B.B.; Damasceno, T.C.M.; Cardoso, J.F.S.; Soares, F.F.F.; Braga, C.C.; Oliveira, M.S.; Silva, L.H.M.; Amorim, R.C.; Cordeiro, M.L.L. Supervision: Mineiro, A.L.B.B.; Paula, N.R.O.; Cardoso, J.F.S. Validation: Mineiro, A.L.B.B.; Paula, N.R.O.; Cardoso, J.F.S. Visualization: Teixeira, L.S.A.; Batista, J.F.; Silva, P.H.F.; Paula, N.R.O.; Mineiro, A.L.B.B.; Damasceno, T.C.M.; Cardoso, J.F.S.; Soares, F.F.F.; Braga C.C.; Oliveira, M.S.; Silva, L.H.M.; Amorim, R.C.; Cordeiro, M.L.L. Writing - original draft: Teixeira, L.S.A. Writing - review \& editing: Teixeira, L.S.A.; Paula, N.R.O.; Mineiro, A.L.B.B.; Cardoso, J.F.S.; Batista J.F.; Silva, P.H.F.

\section{REFERENCES}

ADAMS, D.S.; KLEVJER-ANDERSON, P.; CARLSON, J.L.; MCGUIRE, T.C.; GORHAM, J.R. Transmission and control of caprine arthriris-encephalitis virus. American Journal of Veterinary Research, v.44, n.9, p.1670-1675, 1993. Available from: https://www.ncbi.nlm.nih.gov/pubmed/6625321. Access on: Feb. 052018.

AZEVEDO, S.S.; ALVES, C.J.; BATISTA, C.S.A.; CLEMENTINO, I.J.; SANTOS, F.A.; ALVES, F.A.L. Ocorrência de anticorpos anti-Brucella ovis em ovinos procedentes de quatro municípios do estado do Rio Grande do Norte, Brasil. Agropecuária Técnica, v.25, n.2, p.4550, 2004. Available from: http://dx.doi.org/10.1590/18081657001072012 . Access on: Apr. 182017.

BRASIL. Ministério da Agricultura, Pecuária e Abastecimento. Portaria $n^{\circ} 102$, de 17 de dezembro de 2004. Dispõe sobre o Plano Nacional de Vigilância e Controle da Epididimite Ovina_ Brucella ovis. Diário Oficial da União, Brasília, December 172004.

CLEMENTINO, I.J.; ALVES, C.J.; AZEVEDO, S.S.; PAULIN, L.M.; MEDEIROS, K.A. Inquérito soroepidemiológico e fatores de risco associados à infecção por Brucella ovis em carneiros deslanados do semi-árido da Paraíba. Pesquisa Veterinária Brasileira, v.27, n.4, p.137-143, 2007. Available from: http:// dx.doi.org/10.1590/S0100-736X2007000400002. Access on: Nov. 252017.
EISTEN, S.M. Aspectos inmunológicos en el diagnóstico y control de la epidemitis contagiosa del carnero por Brucella ovis. Arquivos de Medicina Veterinária, v.31, n. 1, p.5-17, 1999. Available from: http://dx.doi.org/10.4067/S0301-732X1999000100001. Access on: Sep. 152018.

GOMES, M.J.P. Gênero Brucella spp. Porto Alegre: FAVET/ UFRGS, 2013.

GREVE, I.C.; SILVA, M.C.A.; TRINDADE, S.; SILVA, D.; MASCARENHAS, M.T.; BAHIA, R.C. Utilização de um antígeno comercial para o teste ELISA indireto na detecção de anticorpos contra a brucelose ovina. Revista Acadêmica Ciência Animal, v.9, n.4, p.379-386, 2011 . Available from: $\mathrm{http} / / / \mathrm{dx}$.doi.org/10.7213/cienciaanimal. v9i4.12440. Access on: Jan. 102018.

INSTITUTO BRASILEIRO DE GEOGRAFIA E ESTATÍSTICA (IBGE). Anuário estatístico do Brasil. 2016. Available from: https:// biblioteca.ibge.gov.br/visualizacao/periodicos/84/ppm_2016_ v44_br.pdf. Access on: Jul. 262018.

MENDONÇA, C.E.D.; MUNHOZ, A.D.; BEZERRA, R.A.; GUIMARÃES, L.A.; ALBUQUERQUE, G.R.; MELO, C.B. Brucella ovis em ovinos: soropositividade e fatores de risco. Ciência Animal Brasileira, v. 18, p.e41635, 2017. Available from: https://doi.org/10.1590/10896891 v18e-41635. Access on: Feb. 102019. 
MUHAMMED, S.I.; LAUERMAN JUNIOR, L.H.; MESFIN, G.M.; OTIM, C.P. Duration of Brucella ovis in ewes. The Cornell Veterinarian, v.65, n.2, p.221-227, 1975. Available from: https://pubmed. ncbi.nlm.nih.gov/1126169. Access on: Feb. 022019.

NIELSEN, K.; SMITH, P.; YU, W.L.; ELMGREN, C.; HALBERT, G.; NICOLETTI, P.; PEREZ, B.; CONDE, S.; SAMARTINO, L.; NICOLA, A.; BERMUDEZ, R.; RENTERIA, T. Validation of a second generation competitive enzyme immunoassay (CELISA) for the diagnosis of brucellosis in various species of domestic animals. Veterinary Immunology and Immunopathology, v.125, n.3-4, p.246-250, 2008. Available from: https://doi.org/10.1016/j. vetimm.2008.02.015. Access on: Jan. 32018.

NOZAKI, C.N.; MEGID, J.; LIMA, K.C.; SILVA JUNIOR, F.F.; VELOSO, C.S. Comparação das técnicas de imunodifusão em gel de ágar e ELISA no diagnóstico de brucelose ovina em cabanhas da região CentroOeste do Estado de São Paulo. Arquivos do Instituto Biológico, v.7 1, n. 1, p.1-5, 2004. Available from: http://www.biologico.sp.gov.br/ uploads/docs/arq/V71_1/nozaki.pdf. Access on: Mar. 092019.

NOZAKI, C.N.; LIRA, N.S.C.; AUGUSTO FILHO, O.; AZEVEDO, H.C.; RODELLO, L.; DASSO, M.G.; BICUDO, S.D.; ANTUNES, J.M.A.P.; MEGID, J. Rapid serum agglutination and agar gel immunodiffusion tests associated to clinical signs in rams experimentally infected with Brucella ovis. Ciência Rural, v.41, n.8, p.1441-1446, 2011 . Available from: http://dx.doi.org/10.1590/SO10384782011000800023 . Access on: Dec. 232016.

OSBOURN, B.I.; KENNEDY, P.C. Pathologic and immunologic responses of the fetal lamb to Brucella ovis. Veterinary Pathology, v.3, n.2, p.1 10-136, 1966. Available from: https://journals.sagepub.com/ doi/10.1 177/0300985866003002O2. Access on: Feb. 022019.
PESSEGUEIRO, P.; BARATA, C.; CORREIA, J. Brucelose: uma revisão sistematizada. Revista Medicina Interna, v.10, n.2, p.91100, 2003. Available from: https://www.spmi.pt/revista/vol10/ vol10-n2-brucelose.pdf. Access on: Sep. 182017.

RIZZO, H.; GREGORY, L.; BERALDI, F.; CARVALHO, A.F.; PINHEIRO, E.S.; PAULIN, L.M. Ocorrência de anticorpos anti-Brucella ovis em ovinos com histórico de distúrbios reprodutivos no estado de São Paulo, Brasil. Arquivos do Instituto Biológico, v.81, n.2, p.99-106, 2014. Available from: http://dx.doi.org/10.1590/1808-1657001072012. Access on: Jun. 252017.

SANTOS, F.A.; HIGINO, S.S.S.; AZEVEDO, S.S.; COSTA, D.F.; FARIAS, A.E.M.; ALVES F.A.L; PAULIN, L.M.; ALVES, C.J. Caracterização epidemiológica e fatores de risco associados à infecção por Brucella ovis em ovinos deslanados do semiárido paraibano. Pesquisa Veterinária Brasileira, v.33, n.4, p.459-463, 2013. Available from: http://dx.doi.org/10.1590/SO 100-736X2013000400008. Access on: Mar. 282017.

SOARES, C.P.O.C.; TELES, J.A.A.; SANTOS, A.F.; SILVA, S.O.F.; CRUZ, M.V.R.A.; SILVA JUNIOR, F.F. Prevalência da Brucella spp. em humanos. Revista Latino-Americana de Enfermagem, v.23, n.5, p.919-926, 2015. Available from: https://doi. org/10.1590/0104-1 169.0350.2632. Access on: Dec. 182016.

SOUSA, M.S. Sincronização do estro e inseminação artificial de ovelhas utilizando água de coco em pó. 2016. 40f. Dissertation (Master in Veterinary Sciences) - Programa de Pós-Graduação em Ciências Veterinárias, Faculdade de Veterinária, Universidade Estadual do Ceará, Fortaleza, 2016. 